\title{
THE COMPARISON PACK CARBURIZING-NITRIDING SUS 316 WITH GAS TYPE WELDING GRADE AND ULTRA HIGH PURITY
}

\author{
Bambang Sulistiyono \\ Department of Mechanical Engineering ${ }^{l}$ \\ Department of Mechanical Engineering \\ State Polytechnic of Malang \\ 9 Jl. Soekarno-Hatta, Malang, Jawa Timur, Indonesia, 65141 \\ bambangsulistyono172.gh@gmail.com \\ Yudy Surya Irawan \\ Department of Mechanical Engineering ${ }^{l}$ \\ yudysir@ub.ac.id \\ Agus Suprapto \\ Department of Mechanical Engineering \\ Merdeka University \\ 62-64 Jl. Terusan Dieng Klojen, Pisang Candi, Kec. Sukun, Kota Malang, Jawa Timur, Indonesia, 65146 \\ agus.suprapto@gmail.com \\ Rudy Soenoko \\ Department of Mechanical Engineering ${ }^{l}$ \\ rudysoen@ub.ac.id \\ ${ }^{1}$ Brawijaya University \\ Jl. Veteran, Ketawanggede, Kec. Lowokwaru, Kota Malang, Jawa Timur, Indonesia, 65145
}

\begin{abstract}
The paper discusses the comparison of pack carburizing-nitriding SUS 316 with gas Nitrogen. The purpose of this study was to increase the hardness and corrosion resistance of SUS 316.

The research used a pack carburizing-nitriding method with gas type Welding Grade (WG) and Ultra High Purity (UHP). The pack carburizing process uses teak wood activated carbon and barium carbonate as a bio-photo catalyst. The specimens were put into a Sealed Steel Container containing teak wood activated carbon, with a depth of $1 \mathrm{~cm}$ below the activated carbon's surface. The test material is then heated until it reaches $850{ }^{\circ} \mathrm{C}$ and is held for 1 hour in a heating furnace. Furthermore, the nitriding process, the specimen is put into a tightly closed nitrogen tube, then nitrogen gas flows until the pressure reaches 41 bar and is held for 24 hours. They are using Welding Grade (WG) and Ultra High Purity (UHP) gas types. Furthermore, microVickers hardness testing, optical microscope, and Scan Electron Microscope (SEM) were carried out.

The results of the study include a. There was an increase in violence by $41.7 \%$ for UHP and WG $(17.3 \%)$. b. The formation of nitride compounds and carbon dissipation on the specimen surface in the UHP carburizing-nitriding pack treatment is more than WG. The formation of a nitride layer is indicated by its fine and dense morphology and film bonding to the substrate. The chemical composition affects the diffusivity of nitrogen atoms in modifying the surface layer of the substrate. The higher the nitride compound formed, the smoother the substrate surface. Also, with UHP treatment, the lower the elemental content of Cr makes SUS 316 more resistant to corrosion. So that SUS 316 UHP can be recommended for use as an implant material.
\end{abstract}

Keywords: Pack Carburizing-nitriding, Nitrogen, Welding Grade, Ultra High Purity, Microstructure, SUS 316.

DOI: $10.21303 / 2461-4262.2021 .001839$

\section{Introduction}

In medicine, especially orthopedic surgery, the use of metal as a substitute for bone is chosen because of its good mechanical stability. However, metals undergo corrosion when they are in body tissue [1]. Therefore, consideration is needed in determining the type of material to be used as an implant. In general, SUS austenitic is chosen. It is because it has an austenitic microstructure at 
room temperature. SUS 316 contains an addition of molybdenum that gives it improved corrosion resistance. Also, SUS 316 has low carbon and high nickel and chromium. Low carbon content does not cause inter-crystalline corrosion. But this type of steel can corrode the body under stressful conditions and when the body is depleted of oxygen.

Examples of using SUS 316 as implants include hip nails, bone screws, and fracture plates [2]. This material's choice is associated with the formation of a thin 'passive film' and self-healing. However, due to the austenite structure, these SUS steels have a low surface hardness and poor wear resistance $[3,4]$.

To improve surface hardness, wear resistance uses diffusion and thermochemical surface treatment techniques, such as carburizing [5], nitriding [6], nitro-carburizing [7], and ion implantation [8]. In all heat treatment processes, the temperature is kept below $500{ }^{\circ} \mathrm{C}$. This is to prevent chromium carbide and nitride formation, which binds the chromium to the matrix, thereby reducing corrosion resistance $[3,7]$.

The use of carburizing packs using charcoal as a carbon producer can increase the corrosion resistance of SUS 304L [8,9]. At the same time, [10] using $\mathrm{CO} / \mathrm{CO}_{2}$ gas on heating 500-700 ${ }^{\circ} \mathrm{C}$ and holding time $30-500$ hours can form a uniform material and a surface that is not crusted on SUS 304. In addition to the nitriding process SUS 316, ion nitriding can harden the specimen surface by $100 \mu \mathrm{m}$ at a temperature of $500{ }^{\circ} \mathrm{C}$ for 24 hours [11].

The use of a carburizing pack with pulverized bone at a temperature of $900{ }^{\circ} \mathrm{C}$, holding time minutes and cooling oil, can increase the tensile strength of mild steel [12].

Meanwhile, [13] examined the characterization of AISI 316L stainless steel implants after boronization. The boronization process was carried out at $850{ }^{\circ} \mathrm{C}, 900{ }^{\circ} \mathrm{C}, 950{ }^{\circ} \mathrm{C}$ and $1000{ }^{\circ} \mathrm{C}$ and holding times of 2.4 and 6 hours. The results showed an increase in surface hardness (more than $1500 \mathrm{VHN}$ ) with a thickness of 12 to $40 \mathrm{~mm}$.

The purpose of pack carburizing - nitriding, which is a method to modify the microstructure to increase the surface hardness of SUS 316 as an implant material. It has various parameters and can be used for microstructural modification, such as temperature, processing time, and gas composition. Pack carburizing process - Nitriding is more economical with a shorter time than other surface hardeners. Pack carburizing-nitriding process is a surface hardening process involving the deposition of a nitride layer and carbon diffusion into the substrate. The Pack carburizing-nitriding process produces nitride compounds and carbon dissipation at grain boundaries. Therefore, nitride compounds can inhibit corrosion, thus increasing the hardness and corrosion resistance of SUS 316 as an implant material.

Research on pack carburizing-nitriding as heat treatment to increase the surface hardness of stainless steel 316. So that this material can be used as a base material for manufacturing valves, engine drive shafts, implant materials and so on.

The effect of using carburizing nitriding packs on stainless 316 will affect the quality of the substitute material. This will be very useful in the use of stainless 316 as a substitute material, as needed. Therefore, it is necessary to research the comparison of pack carburizing-nitriding SUS 316 with gas type welding grade (WG) and ultrahigh purity (UHP), to get implant material that is suitable for the human body.

\section{Materials and methods}

\section{1. Materials}

SUS 316 was used as the specimen in this study. Table 1 shows the chemical composition of the specimens. The research material used SUS 316 with a diameter of $10 \mathrm{~mm}$ and a thickness of $3 \mathrm{~mm}$. then polished with 1200-grit polished paper for a smooth surface. Before heat treatment, the specimens were cleaned using acetone solution. This study used two stages, namely, pack carburizing and nitriding. Fig. 1 shown the experiment it research.

The first stage is the pack carburizing process using teak wood activated carbon and barium carbonate as a bio photo catalyst. The chunks of coconut teak are dried in the sun. Then the pyrolysis process is carried out at $500{ }^{\circ} \mathrm{C}$ for 5-7 hours. The teak charcoal resulting from pyrolysis is immersed in a $30 \%$ solution of barium carbonate for 24 hours to become activated carbon. The finished activated carbon was cleaned and dried in a heating furnace at $110^{\circ} \mathrm{C}$ for 5 hours. 
Table 1

Composition of the SUS 316 (wt. \%)

\begin{tabular}{cc}
\hline Elements Composition & Wt \% \\
\hline $\mathrm{Fe}$ & Balance \\
$\mathrm{C}$ & 0.080 \\
$\mathrm{Cr}$ & 16.000 \\
$\mathrm{Mn}$ & 2.000 \\
$\mathrm{Ni}$ & 10.000 \\
$\mathrm{Mo}$ & 2.000 \\
$\mathrm{Si}$ & 0.750 \\
$\mathrm{P}$ & 0.045 \\
$\mathrm{~S}$ & 0.030 \\
$\mathrm{~N}$ & 0.100
\end{tabular}

Furthermore, the activated carbon is mashed and filtered with a size of 140 mesh. The pack carburizing process begins by inserting the specimen into a Sealed Steel Container containing teak wood activated carbon, with a depth of $1 \mathrm{~cm}$ below the activated carbon's surface. The test material is heated until it reaches $850^{\circ} \mathrm{C}$ and is held for 1 hour in a heating furnace. After that, the Sealed Steel Container containing the specimens was removed from the heating furnace.

In the second stage, the nitriding process, the specimens were taken from the Sealed Steel Container in high-temperature conditions. Furthermore, it is inserted into the nitrogen tube. After the nitrogen tube is closed tightly, nitrogen gas flows until the pressure reaches 41 bars and is held for 24 hours. The type of nitrogen gas uses WG (Welding Grade) and UHP (Ultra High Purity). Furthermore, the Vickers microhardness testing, optical microscope, and Scan Electron Microscope (SEM) were carried out.
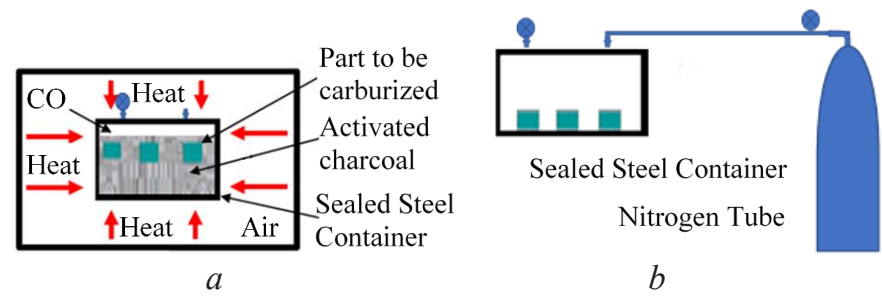

Fig. 1. The experiment setup: $a$ - pack carburizing process; $b$ - nitriding process

Fig. 1 shown the research consists of a pack carburizing process and a nitriding process. Packs carburizing are carried out in a sealed steel container containing activated carbon. While the nitriding process, the specimen is cooled using nitrogen gas type Welding grade and Ultrahigh purity.

\section{2. Characterization of Film, Coating, and Hardness}

The nature and types of nitrides formed in the coating layer relate to the test material's chemical composition. The presence of nitrides formed in the coating layer was confirmed using optical microscopy and SEM. The specimen's surface element content is known from the EDAX test, while the measurement of surface hardness uses a Vickers microhardness tester with a load of $0.5 \mathrm{~N}$.

\section{Results and discussion}

\section{1. Hardness, Film Characterization, and Nitride}

Fig. 2 shows an increase in hardness after pack carburizing-nitriding, using either UHP (41.7\%) and WG (17.3\%) nitrogen. It indicates that there are carbon diffusion and the 
formation of a layer of nitride compounds on the surface of SUS AISI 316. The cooling speed of UHP nitrogen is higher than WG. It is influenced by the purity of the nitrogen content between $95 \%$ and $99.99 \%$. The higher the nitrogen purity, the higher the freezing point, so the greater the ability to form nitride compounds on the specimen's surface.

Fig. 3 shows the diffusion pattern of carbon on the substrate. Carbon dissipates on the structure of SUS 316. The nitride compound layer becomes harder than the substrate. The hardness value on the surface of SUS 316 before treatment was $213 \mathrm{HV}$, while after treatment, it was $302 \mathrm{HV}$ (UHP) and $257 \mathrm{HV}$ (WG). When heating, the molecular bonds at the grain boundaries of SUS 316 are unstable and tend to break easily. At the same time, active carbon atoms surround the specimen. So that carbon atoms easily insert the weakest bond in the substrate.

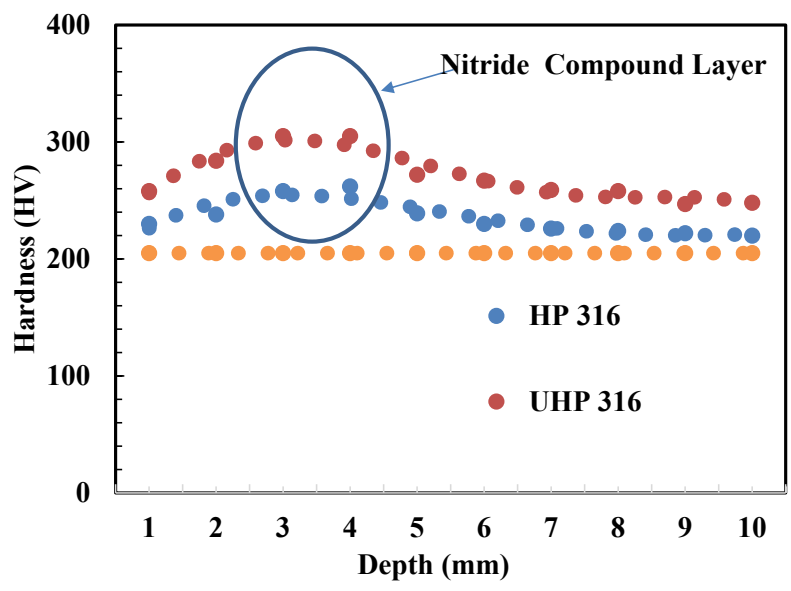

Fig. 2. Comparison of the hardness value of SUS 316 after the pack carburizing-nitriding process

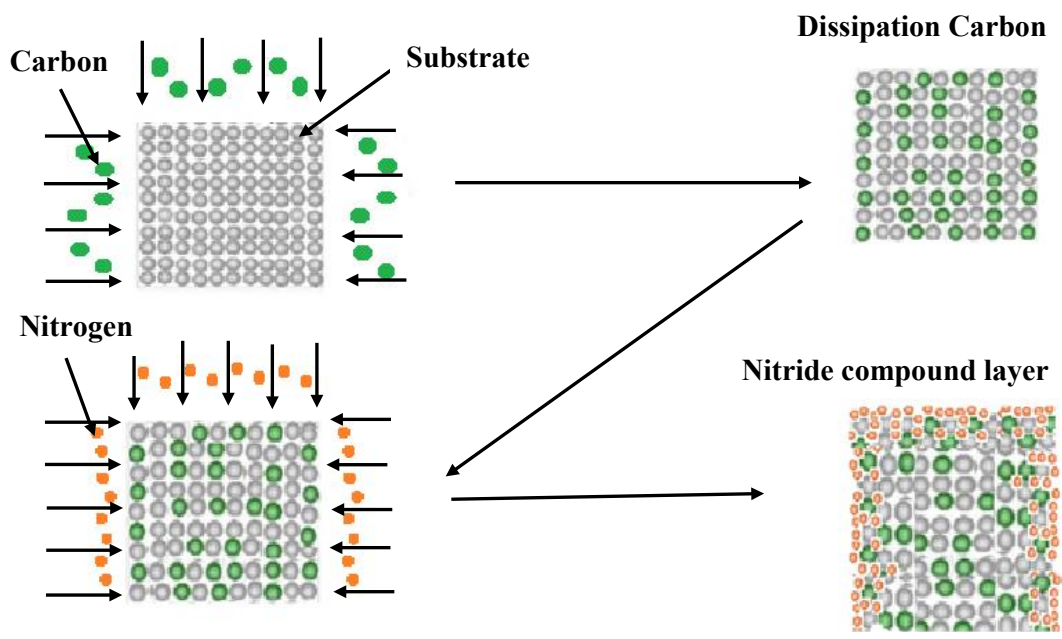

Fig. 3. Carbon diffuse mechanism and formation of nitride compounds on the specimen surface

The nitride layer formation is influenced by the cooling rate and the pressure of the nitride gas on the substrate. After the carbon diffusion process on the subtract, the element composition of SUS 316 is increasingly unstable. Nitrogen atoms will easily stick to the outermost bonds and form nitride compounds, especially the element $\mathrm{Mg}$.

\section{2. Microstructure}

The results of microstructure testing using an optical microscope showed a significant difference. The microstructure of UHP pack carburizing-nitriding is more carbon diffusion at the grain boundaries and the formation of nitride compounds (Fig. 4, 5). 


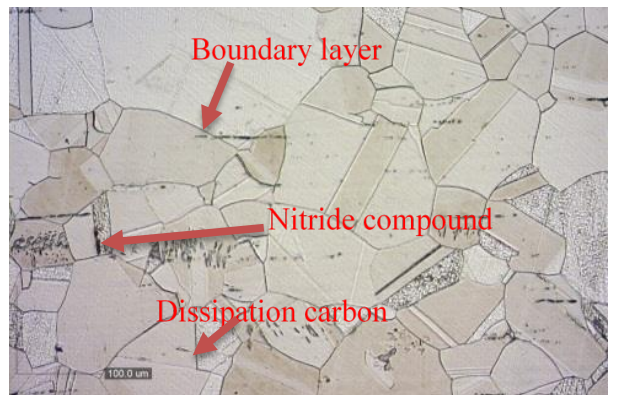

Fig. 4. SUS 316 with Pack Carburizing -Nitriding WG

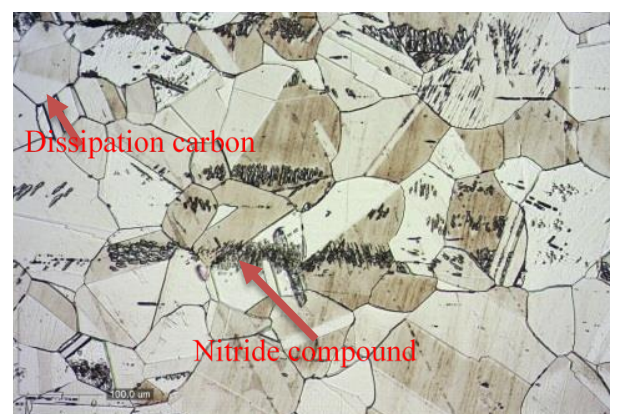

Fig. 5. SUS 316 with Pack Carburizing-nitriding UHP

Fig. 4, 5 show the dissipation of carbon at the grain boundaries and the formation of nitride compounds that bind to the substrate. In pack carburizing with nitriding using UHP gas, the formation of nitride compounds and carbon dissipation on the specimen surface is more than WG. Besides, the grain size in UHP is smaller than WG. So that the hardness is higher UHP than WG.

Based on SEM testing results, there is a clear difference between the SUS 316 standard and the carburizing-nitriding pack using nitrogen gas types WG and UHP Fig. 6-8.

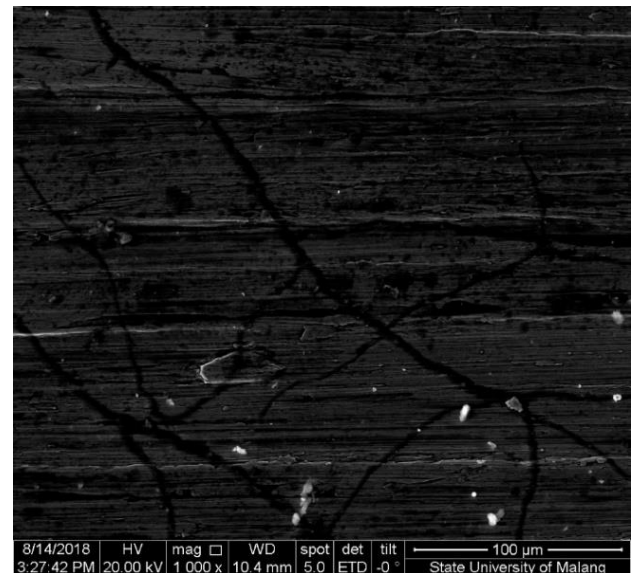

a

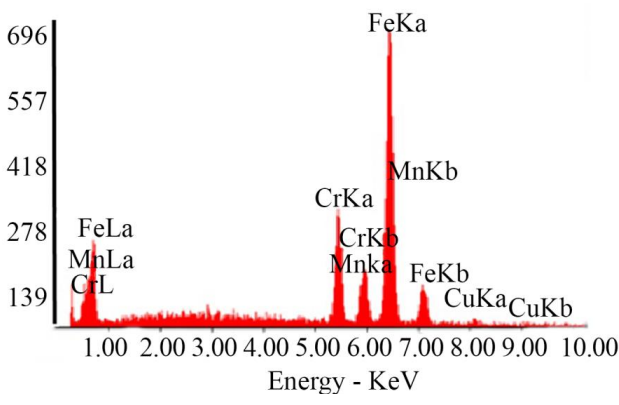

$b$

Fig. 6. Testing results: $a$ - SEM untreated SUS 316; $b$ - EDAX untreated SUS 316

The carbon content was not detected on the specimen surface. While the dominant content elements are FeK (74.28) and CrK (15.29), so they are easy to corrode. The C content was undetectable on the specimen surface. It makes the hardness of SUS 316 around $213 \mathrm{HV}$.

The carbon element dissipates at the grain boundaries, it grains forming a black line at the grain boundaries. Meanwhile, nitrogen forms a nitride compound to bind Mn to the specimen surface, forming a straight, homogeneous line. Besides that, there is a boundary between the substrate and the nitride compound. It is thus increasing the hardness value of the specimen. 


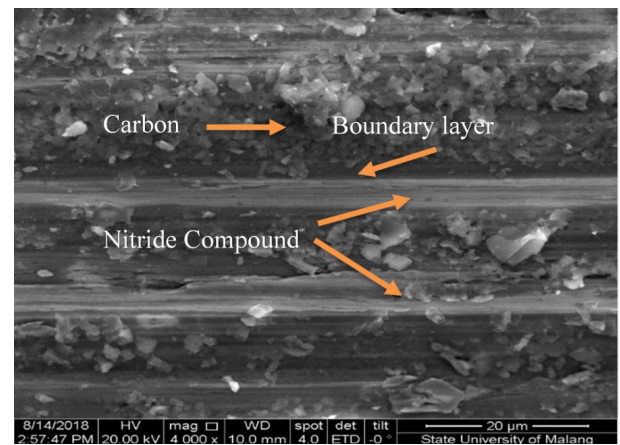

$a$

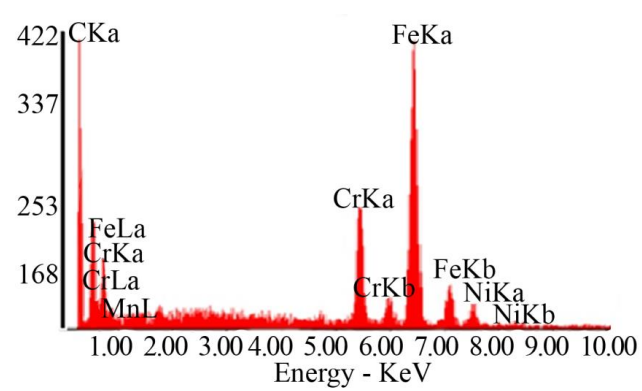

$b$

Fig. 7. Testing Result: $a$ - SEM SUS 316 with pack carburizing-nitriding WG $(\times 1000)$; $b-$ EDAX SUS 316 with pack carburizing-nitriding WG

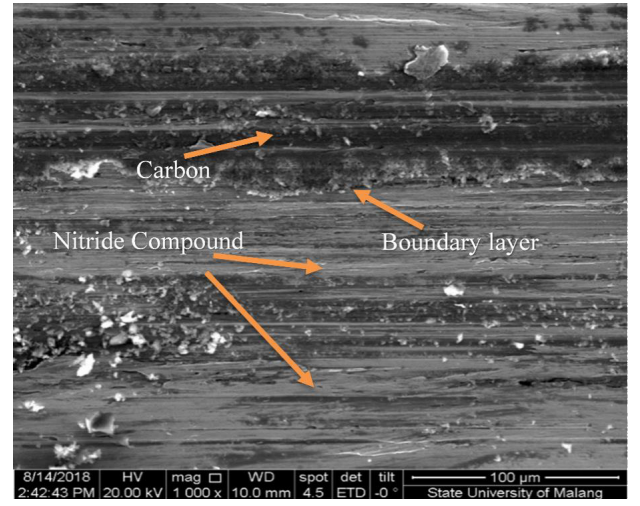

$a$

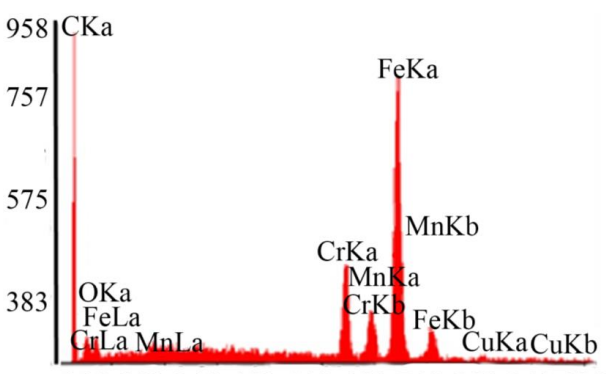

1.002 .003 .004 .005 .006 .007 .008 .009 .0010 .00 Energy - $\mathrm{KeV}$

b

Fig. 8. Test Result: $a$ - SEM SUS 316 with pack carburizing - nitriding UHP $(\times 1000)$; $b$ - EDAX SUS 316 with pack carburizing - nitriding UHP

Fig. 8 shows the composition of the nitride compound. The more it is indicated by, the higher the presence of the MnKb compound. Also, the carbon content is higher than the HP carburizing-nitriding pack. Let's compare the specimens' chemical content with nitrogen cooling WG and UHP types, as shown in Table 2.

Table 2

Comparison of the chemical composition Standard, WG, UHP

\begin{tabular}{cccc}
\hline Composition & Standard Wt (\%) & WG Wt (\%) & UHP Wt (\%) \\
\hline CK & 0.00 & 42.18 & 44.54 \\
OK & 0.00 & 04.84 & 04.14 \\
CrK & 15.29 & 10.40 & 07.84 \\
MnK & 15.01 & 04.89 & 08.04 \\
FeK & 74.28 & 38.77 & 37.37 \\
CuK & 01.43 & 01.50 & 00.86 \\
Matrik & correction & correction & correction
\end{tabular}

Table 2 show the chemical composition due to the different types of nitrogen used affects the elements' appearance onto the specimen surface. SEM test results showed that a nitride layer was formed, indicated by the fine and dense morphology and film bonding on the substrate. The chemical composition affects the diffusivity of nitrogen atoms in modifying the surface layer of the substrate. The higher the nitride compound formed, the smoother the substrate surface. The thickness of the nitride layer is determined by the diffusion ability of nitrogen atoms into the 
substrate and compound with the element Mn. The thinness of the nitride layer causes the peeling or breaking of the nitride layer.

The chemical composition of SUS 316 without treatment with Pack carburizing-nitriding WG and UHP has a striking difference. This difference is what causes the hardness of SUS 316 to increase. C atoms' content in standard conditions was not visible, while with the pack carburizing treatment, both WG and UHP, there was an increase. The C content in WG was $42.18 \%$, while UHP was $44.54 \%$. It means that with the pack carburizing process, there was an addition of carbon elements on the surface of SUS 316. The Cr element's standard content was $15.29 \%$ decreased for WG by $10.40 \%$, and UHP decreased again to 07.84 . It means that the pack carburizing process increases the corrosion resistance of SUS 316. Because the lower the elemental content of $\mathrm{Cr}$, the more resistant to corrosion is SUS 316. Meanwhile, the Mn element between the WG and UHP processes increased from 04.89 (WG) to 08.04 (UHP), this means that the ability to form nitride compounds is greater than UHP than WG.

The diffusion mechanism of nitrogen atoms in the formation of the nitride phase is influenced by the formation of the passive layer, where the diffusion atmosphere of nitrogen shows that the nitrogen concentration in the material is lost or released into the atmosphere because the inert nature of nitrogen will reduce the formation of the passive surface layer. It is supported by the test data, which shows that the nitride phase formed in the nitrogen atmosphere is very small, compared to the air atmosphere's utilization. Nitrogen atoms that do not form a hard nitride phase will be formed in free nitrogen. The phenomenon of free nitrogen formation is strongly influenced by the element chromium, which helps $\mathrm{N}$ atoms' diffusion process by forming an oxide layer.

Based on this study results, where the UHP carburizing-nitriding pack can be recommended as an implant material because, besides increasing hardness, also increases corrosion resistance. The development of this research to get implant materials in the biomedical field that is suitable for the human body condition.

\section{Conclusion}

1. Vickers microhardness examination showed an increase in hardness after pack carburizing-nitriding, using either UHP (41.7\%) or WG (17.3\%) nitrogen.

2. In the optical test, the formation of nitride compounds and carbon dissipation on the specimen surface in the UHP carburizing-nitriding pack treatment was more than WG.

3. In SEM test results, a nitride layer is formed, indicated by the fine and dense morphology and film bonds on the substrate. The chemical composition affects the diffusivity of nitrogen atoms in modifying the surface layer of the substrate. The higher the nitride compound formed, the smoother the substrate surface. With UHP treatment, the lower the elemental content of Cr makes SUS 316 more resistant to corrosion. So that SUS 316 UHP can be recommended for use as an implant material.

Acknowledgments

Thanks to Brawjaya University, which has contributed in the implementation of this research.

\section{References}

[1] Scales, J. T., Winter, G. D., Shirley, H. T. (1961). Corrosion of Orthopaedic Implants. BMJ, 2 (5250), 478-482. doi: https://doi.org/ 10.1136/bmj.2.5250.478

[2] Disegi, J. A., Eschbach, L. (2000). Stainless steel in bone surgery. Injury, 31, D2-D6. doi: https://doi.org/10.1016/s00201383(00)80015-7

[3] Li, C. X., Bell, T. (2004). Corrosion properties of active screen plasma nitrided 316 austenitic stainless steel. Corrosion Science, 46 (6), 1527-1547. doi: https://doi.org/10.1016/j.corsci.2003.09.015

[4] Biserova-Tahchieva, A., Cabrera, J. M., Llorca-Isern, N. (2020). Study of the Thermochemical Surface Treatment Effect on the Phase Precipitation and Degradation Behaviour of DSS and SDSS. Materials, 13 (1), 165. doi: https://doi.org/10.3390/ ma13010165

[5] Susilo, S. H., Suparman, S., Mardiana, D., Hamidi, N. (2016). The Effect of Velocity Ratio Study on Microchannel Hydrodynamics Focused of Mixing Glycerol Nitration Reaction. Periodica Polytechnica Mechanical Engineering, 60 (4), $228-232$. doi: https://doi.org/10.3311/ppme.8894 
[6] Hassan, K. S., Razooqi, A. I., Ridha, M. H. (2020). Mechanical, Pure Fatigue and Corrosion Fatigue Properties of Pack Carburizing Low Carbon Steel Aisi 1020 by Using Waste Organic Materials in 3.5\% Nacl. doi: https://doi.org/10.21203/rs.3.rs-28892/v1

[7] Lo, K. H., Shek, C. H., Lai, J. K. L. (2009). Recent developments in stainless steels. Materials Science and Engineering: R: Reports, 65 (4-6), 39-104. doi: https://doi.org/10.1016/j.mser.2009.03.001

[8] Jiang, T., Odnevall Wallinder, I., Herting, G. (2012). Chemical Stability of Chromium Carbide and Chromium Nitride Powders Compared with Chromium Metal in Synthetic Biological Solutions. ISRN Corrosion, 2012, 1-10. doi: https://doi.org/ $10.5402 / 2012 / 379697$

[9] Susilo, S. H., Asrori, A. (2021). Analysis of position and rotation direction of double stirrer on chaotic advection behavior. EUREKA: Physics and Engineering, 2, 78-86. doi: https://doi.org/10.21303/2461-4262.2021.001707

[10] Czerwinski, F. (2012). Thermochemical Treatment of Metals. Heat Treatment - Conventional and Novel Applications. doi: https://doi.org/10.5772/51566

[11] Inouye, H. (1962). High-temperature reactions of type 304 stainless steel in low concentrations of carbon dioxide and carbon monoxide. doi: https://doi.org/10.2172/4804434

[12] Krastev, D. (2012). Improvement of Corrosion Resistance of Steels by Surface Modification. Corrosion Resistance. doi: https://doi.org/10.5772/33247

[13] Aramide, F. O., Ibitoye, S., Oladele, I. O., Borode, J. O. (2010). Pack carburization of mild steel, using pulverized bone as carburizer: Optimizing process parameters. Leonardo Electronic Journal of Practices and Technologies, 16, 1-12. Available at: https://www.researchgate.net/publication/49596555_Pack_Carburization_of_Mild_Steel_using_Pulverized_Bone_as_Carburizer_Optimizing_Process_Parameters

How to cite: Sulistiyono, B., Irawan, Y. S., Suprapto, A., Soenoko, R. (2021). The comparison pack carburizing-nitriding SUS 316 with gas type Welding Grade and Ultra High Purity. EUREKA: Physics and Engineering, 3, 119-126. doi: https://doi.org/10.21303/ 2461-4262.2021.001839 